\title{
O circuito social da fotografia em Porto Alegre (1922 e 1935)
}

Zita Rosane Possamai ${ }^{1}$

RESUMO: A fotografia crescentemente vem sendo investigada pelos historiadores brasileiros, fazendo surgir diferentes abordagens metodológicas para análise dessas imagens visuais. Componente fundamental nos estudos dessa natureza é o mapeamento do circuito social da fotografia. Nesse âmbito encontra-se um conjunto de informações relacionadas à produção, à circulação e ao consumo da fotografia enquanto imagem visual, criadora e propagadora de determinados imaginários sociais, e enquanto artefato que teve lugar na vida das pessoas em diferentes contextos. Nesse artigo, investigo o circuito social da fotografia na cidade de Porto Alegre, nas décadas de 1920 e 1930, tentando buscar pistas da presença, na vida dos porto-alegrenses, desse engenho da modernidade e das vistas urbanas por ele difundidas. PALAVRAS-CHAVE: Fotografia. Cidade. Imaginário. Imagem.

ABSTRACT: Photography has been increasingly investigated by Brazilian historians, thus bringing about diverse methodological approaches for the analysis of such visual images. A fundamental component in the studies of this nature is research on photography's social circuit. Within this scope, there is a body of information that is related to the production, circulation and use of photography understood as a visual, creative and disseminating image for certain social imaginaries, and as an artifact that had a place in people's lives in different contexts. In this article, the author investigates photography's social circuit in the city of Porto Alegre in the 1920's and 1930's, in an attempt to find clues of the presence of this modern invention in the life of Porto Alegre citizens and of the urban vistas that it disseminated.

KEYWORDS: Photography. City. Imaginary. Image.

mapeamento do circuito social da fotografia constitui-se em etapa fundamental na investigação de imagens fotográficas. Por circuito social da fotografia (FABRIS, 1991 b; LIMA, 1991), compreendo o processo de produção, circulação e consumo não apenas das imagens fotográficas enquanto imagens visíveis no documento fotográfico, mas também da fotografia como artefato (MENESES, 2003). Nessa última acepção, interessa-me ver a fotografia como
1. Doutora em História pela Universidade Federal do Rio Grande do Sul (UFRGS) e docente do Centro Universitário Metodista IPA. E-mail:zita@ cpovo.net 
2. Esse texto aborda aspectos da tese da autora Cidade fotografada: memória e esquecimento nos álbuns fotográficos Porto Alegre, décadas de 1920 e 1930.2 v. Tese (Doutorado em História) -Programa de Pós-Graduação em História, Ins tituto de Filosofia e Ciências Humanas, Universi dade Federal do Rio Grande do Sul, Porto Alegre, 2005. Esta pesquisa teve o apoio da Fundação de Amparo à Pesquisa do Rio Grande do Sul objeto que fazia parte da realidade social, tomando assento na vida das pessoas de determinado período histórico. Neste texto, apresento e discuto as informações sobre o circuito social da fotografia na cidade de Porto Alegre, nas décadas de 1920 e 1930, na tentativa de verificar a dimensão da relação entre os portoalegrenses e o universo fotográfico. Os anúncios publicitários e notas, localizados em revistas ilustradas, nos almanaques e nos jornais, constituem-se em fontes preciosas para o estudo proposto. Nesses documentos busquei referências sobre fotógrafos, estúdios fotográficos, produtos fotográficos e estabelecimentos que os comercializavam ou prestavam serviços fotográficos, preços das fotografias e dos produtos fotográficos².

Fotógrafos e estúdios fotográficos em Porto Alegre

A fotografia mantinha lugar assegurado em Porto Alegre desde a segunda metade do século XIX. A maioria dos retratistas estrangeiros que viajavam pelo interior do Rio Grande do Sul tirando fotografias não deixava de passar antes por Porto Alegre (ALVES, 1998). Um dos primeiros a se estabelecer na cidade, como fotógrafo profissional, foi o daguerreotipista italiano Luiz Terragno (DAMASCENO, 1974; KOSSOY, 2002a). Além do daguerreótipo, aí eram encontrados produtos, equipamentos e procedimentos fotográficos diversos, alguns dos quais recém-inventados na Europa, como a fotografia estereoscópica, a máquina ampla que permitia fotografar um grupo grande de pessoas, e o ambrótipo com o colódio-úmido, que permitia a confecção de fotografias de forma mais rápida.

No final do século XIX, poderiam ser identificados em Porto Alegre os estabelecimentos de aproximadamente vinte fotógrafos, entre os quais se destacavam cinco estúdios fotográficos, cujos proprietários eram o espanhol João Antonio Iglesias, os italianos Irmãos Ferrari, o italiano Virgílio Calegari, o alemão Otto Schönwald e Innocencio Barbeitos (SANTOS, 1998).

Entre todos esses, os que gozaram de maior prestígio foram os estúdios dos Irmãos Ferrari e de Virgílio Calegari. Eram italianos e radicaram-se em Porto Alegre, no final do século XIX, onde passaram a dedicar-se ao ofício da fotografia. Esses estúdios fotográficos acabaram competindo entre si, não apenas por terem sua localização no centro da cidade, mas também pela qualidade esmerada de seus trabalhos (DAMASCENO, 1971).

O modesto estúdio dos Ferrari foi fundado em 1871, pelo pai Rafael, e localizava-se na rua da Ponte, levando muitos anos para firmar-se entre os porto-alegrenses. Ao aposentar-se, seus filhos Carlos e Jacintho sucederam-no no ofício, criando o estúdio Ferrari \& Irmão, localizado na rua Duque de Caxias, 473. Tornaram-se bastante conhecidos quando, em 1889, lançaram uma coleção de vistas de Porto Alegre e arredores sobre cartão, em tamanho aproximado de $24 \mathrm{~cm} \times 30 \mathrm{~cm}$. A coleção de vistas dos Irmãos Ferrari ganhou grande aceitação 
entre o público, tornando o talento de seus autores de tal forma reconhecido que, em 1892, o Governo Federal thes encomendou fotografias urbanas para a Exposição Colombiana. Os Ferrari eram também retratistas, vindo a associarse com os pintores Boscagli e Carlos Fontana, num primeiro momento, e Frederico Trebbi, posteriormente, a fim de contentar a freguesia apreciadora das imagens fotográficas retocadas. No entanto, muito da ascensão dos irmãos deveu-se à realização e à ampla comercialização de suas vistas urbanas, que não apenas difundiram sua arte, mas também a Porto Alegre fin-de-siècle. Os Ferrari conseguiram prosperar de tal forma, que montaram um dos mais luxuosos ateliers fotográficos da virada do século, chegando mesmo a ter que fechar seu estabelecimento por excesso de trabalho. Nessa época provavelmente já teriam se estabelecido na principal via comercial do centro da cidade, no número 254 da rua dos Andradas.

patrício dos Ferrari, Virgílio Calegari, aprendera seu métier no final do século XIX com outro fotógrafo radicado na cidade, o espanhol João Antonio Iglesias. Quando os Ferrari eram já bastante conhecidos por suas vistas urbanas, Calegari montava seu primeiro atelier, em 1893, localizado na rua do Arroio, de onde se transferiu, após três anos, para a rua dos Andradas. Realizou várias exposições nas vitrines de estabelecimentos comerciais, prática usual no período, assim como foi agraciado por vários prêmios nacionais e internacionais no desenrolar de sua trajetória profissional. Calegari destacou-se como o fotógrafo das autoridades locais, realizando o retrato de figuras políticas proeminentes da sociedade porto-alegrense. A sala de espera de seu estúdio reunia muitos desses retratos de figuras destacadas da República, numa época em que os artistas utilizavam seu local de trabalho como uma espécie de galeria de exposições das imagens fotográficas por eles elaboradas. Apesar de ter sido reconhecido sobretudo como exímio retratista, Virgílio Calegari também realizou muitas vistas de Porto Alegre, vindo, inclusive, a reunir algumas delas em um álbum fotográfico, publicado no início do século XX.

Como pode ser visto, a fotografia marcou presença na Porto Alegre do final do século XIX e início do século XX. Essa presença, por um lado, atestava a atualização da capital mais meridional do Brasil em relação às inovações técnicas provenientes da Europa, graças principalmente à chegada desses fotógrafos estrangeiros. Por outro, demonstrava a assimilação desse novo engenho, pelo menos entre as camadas mais abastadas da sociedade portoalegrense, que faziam das imagens fotográficas objeto de consumo.

A recepção da fotografia em Porto Alegre não se deu apenas pela aquisição dos retratos realizados em estúdio, forma através da qual os indivíduos alcançavam uma representação visual de si em consonância com os padrões comportamentais vigentes na Belle Époque, mas também pelo consumo das imagens de vistas urbanas da cidade. Nesse caso, significava transpor para a representação visual aspectos urbanos que também obedecessem um ideal de progresso almejado pelas elites e pelos republicanos no poder. 
Um desejo de modernidade urbana

Certamente, a Porto Alegre da virada do século XIX para o XX ainda não apresentava no seu espaço urbano os traços da modernidade pretendida. Mesmo que as vistas dos Irmãos Ferrari e de Calegari - à luz das transformações ocorridas na cidade nas décadas seguintes e à luz das imagens fotográficas produzidas nas décadas de 1920 e 1930 - sejam representações visuais de uma cidade que ficara no passado, não deixam de ser lampejos da representação de uma cidade que ensaiava os primeiros passos em direção ao progresso almejado.

De fato, a Porto Alegre colonial da virada do século XIX para o XX fazia-se notar, principalmente, pelos seus problemas urbanos. Aumento demográfico, carência de água potável, inexistência de redes de esgotos, ruas mal pavimentadas e mal iluminadas eram algumas das questões a serem equacionadas pelas cidades brasileiras no advento da República (SOUZA; DAMASIO, 1993). Com Porto Alegre não era diferente. Já na primeira década do século XX, a cidade vira praticamente dobrar de tamanho o número de seus habitantes (SINGER, 1974). Ocupando a exígua área do centro histórico, às margens do Guaíba, esse contingente populacional tornava mais prementes os problemas relativos à moradia, ao saneamento, aos transportes e à circulação.

Para enfrentar a situação, vários serviços públicos haviam sido implantados na segunda metade do século XIX: encanamento de água (1861), linha de bondes (1864), Mercado Público (1 870), iluminação a gás (1874), serviços telefônicos (1884). Naquele contexto, a cidade ganhara grande impulso econômico por ser o escoadouro da produção agrícola das colônias imigrantes, destinada ao mercado interno do centro do Brasil. Via, ademais, aumentar a complexidade das relações sociais na transição do trabalho escravo para o trabalho livre. Não tardaria muito para que o capital acumulado nas atividades comerciais rumasse para a atividade industrial. Com as fábricas, veio o operariado, classe social com demandas próprias e até então desconhecidas na pacata Porto Alegre colonial.

A cidade, assim, continuava a crescer e, já em 1891, registrava-se a elaboração de um plano para a cidade, que almejava atacar o problema de saneamento, cuidando do embelezamento da urbe (PESAVENTO, 1999). No início do século XX, Porto Alegre ainda não havia resolvido vários de seus problemas urbanos, que passaram a receber tratamento mais sistemático no governo de José Montaury de Aguiar Leitão (1897-1924), quando foram implementadas várias benfeitorias. Um sistema de esgotos veio a resolver a antiga e precária coleta de dejetos. A iluminação a gás e querosene foi substituída pela iluminação elétrica, fornecida pela Cia. Fiat Lux, e ampliada com a criação da Usina Municipal, em 1908. Nesse mesmo ano, os bondes puxados a burro foram substituídos pelos bondes elétricos. As ruas receberam calçamento. Os largos, como o da Forca e o do Paraíso, foram transformados na praça da 
Harmonia e praça XV de Novembro. $\bigcirc$ Campo da Redenção recebeu tratamento paisagístico para receber a Exposição de 1901.

Além de todos esses melhoramentos, ocorria, nesse período, a modificação do cenário arquitetônico porto-alegrense, que privilegiava construções mais imponentes. Nas duas primeiras décadas do século XX, foi construída uma significativa quantidade de edificações com característica arquitetônica majestosa e ornamental, substituindo a seqüência de casarios oitocentistas desprovidos de ornamentações em suas fachadas (DOBERSTEIN, 1992). Entre essas novas construções, estavam os prédios da Intendência; dos Correios e Telégrafos; da Delegacia Fiscal; da Biblioteca Pública; e do Palácio Piratini. Constituíam-se, pela mistura de estilos, em exemplares do Ecletismo, que "foi a linguagem utilizada nos edifícios formadores do cenário que representou a concretização de uma vida urbana considerada moderna, segundo o imaginário social da época" (BELLO, 1997, p. 103). Essas edificações foram elementos importantes na composição de uma nova visualidade urbana, da qual os fotógrafos tiraram proveito na elaboração de imagens fotográficas em consonância com o ideal de modernidade almejado.

A presença da fotografia na cidade desde o século XIX deixava claro, por parte daqueles poucos que a consumiam, o desejo de estar em sintonia com o que então era concebido como moderno, com as inovações tecnológicas, com o dernier cri escutado na Europa. A cidade, assim, preparava-se para alçar vôos mais altos, seja resolvendo problemas infra-estruturais, seja cuidando de sua imagem urbana. As lentes atentas dos fotógrafos acompanhavam pari passu esses movimentos, ao mesmo tempo em que inseriam a fotografia como um elemento fundamental na criação dessa nova imagem visual, alimentando o imaginário urbano moderno.

Os estúdios fotográficos da cidade mais importantes na virada do século continuavam suas atividades, que perduraram até meados da década de trinta, quando vieram a falecer seus criadores, Virgílio Calegari e Jacintho Ferrari. Na década de 1920, pude observar a presença de aproximadamente duas dezenas de fotógrafos exercendo suas atividades em Porto Alegre lquadro na página seguinte). Na mesma década, encontrei registro da Photographia Ferrari, localizada na rua dos Andradas 254, provavelmente pertencente a apenas um dos dois irmãos. Assim, nas décadas pesquisadas, os dois ateliers mais consagrados da cidade no início do século XX mantiveram sua localização na principal artéria comercial do centro da cidade, a rua dos Andradas, onde continuavam disputando a sua clientela entre si e também com novos estabelecimentos fotográficos. Entre esses, estava a Photographia Popular, de propriedade de Carlos Gatti, localizada inicialmente na rua Marechal Floriano, mas que, em seguida, abrirá uma filial também na rua dos Andradas. Na década de 1920, Virgílio Calegari e Jacintho Ferrari continuavam a merecer a consideração dos porto-alegrenses como os dois mais importantes fotógrafos da cidade. E foi com pesar que a cidade assistiu o desaparecimento, na década de 1930, desses dois expoentes da arte fotográfica na cidade. 
Fotógrafos e Estúdios Fotográficos de Porto Alegre (1920-1930)

\begin{tabular}{|c|c|c|}
\hline Virgilio Calegari & 1922-1932 & Andradas 171 \\
\hline Jacintho Ferrari / Photographia Ferrari & $1922-1935$ & Andradas 254 \\
\hline Photographia Ferrari & 1930 & Andradas 1500 \\
\hline Otto Schöenwald & 1922-1924 & Ramiro Barcellos 229 \\
\hline Barbeitos Irmãos & 1922-1924 & Avahy 64 \\
\hline Álvaro Barbeitos / Photographia Barbeitos & 1922 & Avahy 64 \\
\hline Innocencio Barbeitos / Photographia Ideal & $1922-1924$ & José do Patrocínio 91 \\
\hline Augusto Barbeitos & $1922-1923$ & 13 de Maio 21B \\
\hline Augusto Barbeitos & 1924 & av. Redempção \\
\hline Carlos Gatti & $1922-1923$ & Mal.Floriano 131 \\
\hline Carlos Gatti / Photo Popular & 1924-1927 & Mal. Floriano 130 \\
\hline Carlos Gatti / Photo Popular & 1926 & $\begin{array}{l}\text { Mal. Floriano } 132 \\
\text { praça Marechal } \\
\text { Deodoro }\end{array}$ \\
\hline Carlos Gatti & 1923-1927 & Andradas 225 filial \\
\hline Carlos Gatti / Photo Popular & 1926-1927 & Andradas 212 filial \\
\hline Photo Popular & 1930 & Riachuelo 148 \\
\hline Adalberto Rabello & 1922 & José do Patrocínio 60 \\
\hline R. Freudenfeld / Photographia Victoria & 1922-1934 & $\begin{array}{l}\text { Cristóvão } \\
\text { Colombo 40, } 41\end{array}$ \\
\hline Innocencio Rollis & 1922 & av. Eduardo \\
\hline Pedro Campani & 1924-1926 & av. Bom Fim 126 \\
\hline $\begin{array}{l}\text { Oliveira e Steigleder/Photo } \\
\text { Electrica }\end{array}$ & & $\begin{array}{l}\text { Riachuelo } 352 \\
\text { (praça do Portão) }\end{array}$ \\
\hline Nicolau Marquis & 1923 & Fernando Gomes 4 \\
\hline Kathie Scepka / Fotografia Rembrant & 1926 & Mal. Floriano 112 \\
\hline Eugenio Tosca / Officina Photogravura & 1924 & Andrade Neves 56 \\
\hline Leo Dutra & 1922 & \\
\hline Photographia Pacheco e Dutra & 1926 & trav. Itapiru I \\
\hline Photographia Azevedo e Dutra & 1928-1935 & $\begin{array}{l}\text { trav. Itapiru, esquina } \\
\text { r. dos Andradas }\end{array}$ \\
\hline Fotografia Dutra & 1935 & \\
\hline Azevedo Foto & 1935 & Andradas 1512 \\
\hline Studio Photographico E. Pacheco & 1928-1931 & $\begin{array}{l}\text { Andradas } 1383 \\
\text { (antigo 447/448?) }\end{array}$ \\
\hline
\end{tabular}




\begin{tabular}{lll}
\hline N. Breitman / Photographia Aurora & $1927-1933$ & av. Bom Fim 126 \\
\hline Photo Aurora & 1930 & Bragança 48 ? \\
\hline Foto Alberto & 1933 & \\
\hline Sartini & 1935 & \\
\hline Kurt Geissler & $1930-1935$ & \\
\hline O. Hampe & 1930 & \\
\hline Carlos Ferrari & $1930-$ & \\
\hline Ademar Barcelos & 1932 & Andradas 1500 \\
\hline Kováck & $1933-1935$ & \\
\hline Plinio Tamagnoni & $1934-1935$ & Edifício Bastian Pinto \\
\hline Lino Hopfe & 1935 & \\
\hline Studio d'Avila & 1935 & Pinto Bandeira 513 \\
\hline Foto Paris & 1935 & \\
\hline Tabacaria Alpha & 1935 & \\
\hline José Wollmann & 1928 & \\
\hline A. Steigleder Photo Electrica & 1930 & Garibaldi 1214 \\
\hline Photo Abelheira Gaelzer \& Comp. & 1932 & praça Conde de Porto \\
\hline Leopoldo Gaelzer & & Alegre 30 \\
\hline Schroder & 1933 & Andradas 1498 \\
\hline Vídarte & 1935 & \\
\hline Albino Wulff & 1935 & \\
\hline & & Garibaldi 1 153 ou 1163 \\
\hline
\end{tabular}

Os estúdios pertencentes aos fotógrafos de maior prestígio localizaremse no centro da cidade demonstra a importância que esta área tinha na configuração urbana de Porto Alegre. Para o centro da cidade convergiam as iniciativas de projetos e propostas de remodelações do espaço urbano que foram elaboradas e debatidas nas primeiras décadas do século XX, como o Plano Moreira Maciel, surgido em 1914 e executado a partir da década de 1920. O Plano Geral de Melhoramentos coadunava-se, então, com uma tendência da época de buscar uma visão de conjunto da cidade e não apenas propor ações para determinados setores urbanos (SOUZA; DAMASIO, 1993). No projeto de Maciel estavam presentes as preocupações básicas relacionadas à circulação, à higiene e ao embelezamento da cidade e, para atendê-las, o engenheiroarquiteto propôs o alargamento de várias ruas, a abertura de amplas avenidas, a arborização das vias e a remodelação de praças, parques e jardins. Grande parte das propostas do Plano de Moreira Maciel privilegiava a área central de Porto Alegre - concentração de atividades e pessoas -, que necessitava ter 
3. Sobre a relação entre a estatuária presente em várias edificações públicas construídas na pri meira década do século XX em Porto Alegre e a difusão da doutrina positivista, ver DOBERSTEIN, 1992 resolvido, principalmente, o problema de acesso dos bairros fabris - São João e Navegantes - até o Cais do Porto, em construção. Além disso, o crescimento da cidade em direção aos arrabaldes impunha o enfrentamento da dificuldade e morosidade de circulação entre as zonas Norte/Sul e a área central.

O Plano Maciel, dessa forma, no momento de sua elaboração, aglutinou os preceitos de um novo ideário urbano que passava a predominar no imaginário social das elites republicanas e que transportava vários desses traços ao espaço da cidade. A cidade colonial, com suas ruas estreitas e suas construções modestas, não atendia este novo ideal urbano. A cidade oitocentista enquanto estrutura a ser valorizada constitui-se em objeto de preservação muito recente. Ao contrário, embora desenhasse sobre o traçado intramuros ao abrir avenidas e alargar várias ruas, a preocupação do Plano ia no sentido de sanear e de higienizar a cidade, retirando becos e ruelas estreitos, característicos do traçado espontâneo da Porto Alegre colonial.

Ao instaurar esse novo ideário da cidade moderna no papel, o Plano Maciel deu os primeiros passos decisivos na construção do esquecimento da cidade mais antiga. E esse esquecimento foi construído concomitantemente com a edificação da memória da cidade moderna. Ao lado de imagens que permaneceram desse período, como imagens fotográficas, edificações e traçados urbanos preservados, o plano constituiu-se em traço que possibilita ao historiador aproximar-se das idéias e representações que nortearam os homens daquela época. O plano, nesse sentido, pode ser considerado sonho e desejo daqueles que pensaram e projetaram a cidade. No entanto, mais que sonho, passou a fazer parte da vida da cidade, no momento em que muitas das suas propostas deixaram o papel e foram transpostas ao espaço urbano. Porém, antes que tal intento tomasse as ruas e transformasse o espaço em verdadeira cirurgia urbana, tomou forma nas mentes dos republicanos da época.

Desde fins do século XIX, o grupo republicano no poder começara a colocar a capital do estado como "cartão de visitas" (BAKOS, 1996, p. 15) que apresentava o Rio Grande do Sul ao restante do país. Ancorados nos preceitos positivistas de alcançar o desenvolvimento harmonioso da sociedade não descuidando da agricultura, da pecuária, do comércio e da indústria, o espaço urbano foi utilizado como papel em branco, onde muitas dessas idéias tomaram forma, inclusive simbólica. Exemplo deste aspecto pode facilmente ser percebido em monumentos edificados em praças e espaços verdes, nas linhas de imponentes prédios e em conjuntos escultóricos cuidadosamente colocados nas fachadas ${ }^{3}$.

Dessa forma, a cidade, no contexto da república positivista gaúcha, foi um locus privilegiado para a disseminação do imaginário ancorado no ideário de modernidade urbana. O Plano Maciel, ao lado de intervenções já processadas na cidade, como os melhoramentos urbanos e a edificação de imponentes monumentos, vinha a ter importância fundamental ao propor para a urbe um novo desenho, de acordo com este novo ideário. Condensou, neste sentido, o sonho e o desejo das elites republicanas naquele momento. Como projeto no 
papel, no entanto, não levará muito tempo para tomar o espaço concreto da cidade.

Foi a administração Otávio Rocha (1924-1928) que iniciou algumas das mais importantes intervenções no espaço urbano propostas pelo Plano de 1914. A atuação do intendente envolveu a melhoria dos serviços públicos e uma total remodelação do centro da cidade, acompanhada de uma legislação que envolveu desde normas para as novas construções até o comportamento citadino dos indivíduos. Não à toa, Otávio Rocha recebeu cognomes de o "Grande Remodelador" ou o "Passos Porto-Alegrense" , em alusão ao realizador da reforma urbana da cidade do Rio de Janeiro no início do século.

A remodelação do centro da cidade compreendia, principalmente, a abertura da avenida Julio de Castilhos, o alargamento e prolongamento da rua General Paranhos, denominada, a partir de então, Borges de Medeiros, e o prolongamento e alargamento da rua São Rafael e conexão desta com a rua 24 de Maio, que também deveria ser alargada. As obras escolhidas, dessa forma, obedeceram uma necessidade básica, o problema viário, já presente no plano de 1914, ao qual se agregou a preocupação com a higiene e o embelezamento da cidade.

Ainda outras medidas foram tomadas para dar à cidade maior beleza. Os passeios de lajedo foram substituídos por outros, de mosaico, cimento ou granito; a rede de iluminação do centro da cidade foi totalmente remodelada; obras de arte foram adquiridas para embelezar a urbe; uma legislação especial foi aprovada regulamentando as novas construções.

Amplas avenidas abertas, ruas alargadas, praças e espaços verdes remodelados. As transformações, no entanto, ultrapassavam o novo desenho dado ao espaço urbano. Paulatinamente, instaurava-se uma nova maneira de viver na cidade, que passava por hábitos, comportamentos e sociabilidades diferenciadas daquelas práticas tradicionais vivenciadas no âmbito da cidade colonial. As festas populares tradicionais, como os festejos de São João e a Festa do Divino, foram deslocadas das praças do centro para os arrabaldes (MONTEIRO, 1995). A área central destinava-se às práticas que se coadunavam com o novo ideário de modernidade. Cafés, confeitarias, restaurantes, teatro e cinema montam o palco onde se encenam os gestos, as caras e as bocas da burguesia urbana. Assistir aos concertos do Auditório Araújo Viana, na Praça da Matriz, freqüentar o Clube do Comércio, desfilar de automóvel no Carnaval ou fazer o footing na rua da Praia fazia parte dos novos hábitos modernos urbanos que passavam a tomar parte na vida porto-alegrense das camadas sociais mais favorecidas.

Assim como a fotografia tirou proveito das novas edificações monumentais na virada do século, os fotógrafos não deixaram passar desapercebidas as mudanças operadas no espaço urbano nas décadas de 1920 e 1930, colaborando na criação e difusão de um imaginário moderno através das imagens fotográficas. Não apenas os novos traçados viários compuseram essa nova visualidade, mas também as sociabilidades, que tinham na presença das pessoas nas ruas uma marca digna de nota. Mas não bastava 
apenas estar na rua vivenciando os espaços transformados, era mister ser visto e deixar-se fotografar. A visualidade moderna, dessa forma, de acordo com esse imaginário, era criada não apenas por meio das reformas urbanas e dos novos hábitos, mas também através de uma forma especial de representar visualmente esse instante condensado num espaço e num tempo precisos. A fotografia, assim, ao lado do cinema, constituiu-se no meio tecnológico capaz de representar visualmente esse momento fugaz de experiência da modernidade.

Por todas essas razões, os anos vinte e trinta do século XX, em Porto Alegre, constituíram-se em marco, no que se refere à disseminação de um novo projeto de cidade, calcado no imaginário moderno. Idealizado pelos republicanos positivistas, toma sua primeira forma no Plano de Maciel, na década de 1910; nas décadas seguintes, deixa o sonho de papel, passando a conformar importantes áreas urbanas, através de várias medidas implementadas que têm, na abertura de amplas avenidas e na remodelação de espaços verdes, a sua maior visibilidade.

Não é à toa, dessa maneira, que os principais estúdios fotográficos procurassem localizar-se na área central de Porto Alegre, preferencialmente na sua principal artéria comercial, a rua dos Andradas. Ora, a fotografia como engenho moderno, invenção tecnológica relativamente recente, era signo que marchava de braços dados com o advento das metrópoles. Nessa Porto Alegre com seu centro remodelado e com parte de sua população ensaiando novos hábitos mundanos, os estúdios fotográficos eram portas de entrada ao mundo da representação visual, ao mesmo tempo em que compunham a visualidade urbana, ao lado dos cafés, dos cinemas, das vitrines e das confeitarias. Tal como o retrato fotográfico que possibilitava dar a ver o indivíduo, o estúdio valorizava a visibilidade do seu espaço, como forma de tornar também visível a entrada nesse espaço daqueles que tivessem acesso ao retrato fotográfico. $\bigcirc$ estúdio localizado no espaço urbano mais movimentado da cidade, tal como a fotografia, entrava na trama do ver e ser visto, compondo um modo de vida, no qual a visualidade era componente essencial.

Compreendendo este aspecto dos novos tempos, alguns fotógrafos, mesmo localizando-se nos bairros mais longínquos de Porto Alegre, não descuidavam de mostrar suas imagens entre os transeuntes das ruas do centro. Assim, por exemplo, o fotógrafo alemão Otto Schönwald, cujo estúdio funcionava na rua Ramiro Barcellos, no bairro Moinhos de Vento, quando realizava um trabalho de destaque, procurava expô-lo nas vitrinas da loja Preço Fixo, localizada na rua dos Andradas (DAMASCENO, 1974).

Assim, é de se supor que, fugindo da localização no centro da cidade, com raríssimas exceções, estavam aqueles estúdios de menor porte, vários deles identificados no período entre o final do século XIX e início do século XX, e que continuavam abertos nas décadas investigadas. Os Irmãos Barbeitos dispunham de estúdios em separado, localizados nas imediações do bairro Cidade Baixa, sendo que aquele de Augusto Barbeitos, nos primeiros anos da década de 1920, aparece localizado na avenida 13 de Maio, no bairro Menino Deus, e na avenida Redempção, no bairro Bom Fim. Ainda neste último bairro, registrou- 
se a presença do fotógrafo Pedro Campani e, nos últimos anos da mesma década e primeiros anos da década seguinte, da Photographia Aurora, de propriedade do imigrante ucraniano Natan Breitman. Esse imigrante de origem judaica era auxiliado por seu filho Sioma, que, em 1927, instalava seu atelier próprio na avenida Marechal Floriano, no centro de Porto Alegre.

A localização da Photographia Aurora no bairro Bom Fim, no decorrer da década de 1920, apontava a expansão da malha urbana em direção aos arrabaldes, que, além de residências, reuniam estabelecimentos comerciais e de serviços crescentemente utilizados pela população. A família Breitman direcionava, então, seu trabalho a uma clientela de origem judaica, moradores predominantes nos arredores do bairro onde estava localizado o estúdio, da mesma forma que procedera seu colega de profissão, o alemão Otto Schönwald em relação aos imigrantes de alemães e seus descendentes, moradores do bairro Moinhos de Vento e imediações.

Na avenida Cristóvão Colombo registrou-se a presença da Photographia Victoria, de R. Freudenfeld. Encontrou-se, ainda, o fotógrafo Inocêncio Rollis, cujo estúdio na avenida Eduardo, Zona Norte de Porto Alegre, configurava-se como o estabelecimento fotográfico localizado no arrabalde mais afastado do centro da cidade.

Na década de 1930, a quantidade de estúdios fotográficos presente na cidade manteve a mesma proporção observada na década anterior. Outros fotógrafos e estúdios localizados nesse período foram Sartini, Kurt Geissler, $\bigcirc$. Hampe, Ademar Barcelos, Kovack, Plinio Tamagnoni, Lino Hopfe, Studio Fotografia, Fotografia Paris, Albino Wulff. Alguns deles, pela ausência de registros fotográficos nos acervos existentes, são praticamente desconhecidos.

Na segunda metade dos anos vinte, encontrei o registro da Photo Pacheco e Dutra, localizada na travessa Itapiru, cujos proprietários associados eram Pacheco 5 e Olavo Dutra. Para o final daquela década, o primeiro fotógrafo estava presente nas assinaturas das imagens fotográficas apenas como Studio Pacheco, enquanto o segundo veio a constituir sociedade com o artista Augusto Azevedo, passando a assinar as imagens fotográficas como Photografia Azevedo Dutra, cujo estabelecimento tinha dois endereços, na mesma travessa Itapiru e na rua dos Andradas. As fotografias publicadas na Revista do Globo contêm, na sua quase totalidade, a assinatura desse estúdio, cujos anúncios pude encontrar pelo menos até 1937. No entanto, ainda foram localizados, em 1935, anúncios de Azevedo Foto, levando a crer que, mesmo se mantendo a sociedade entre ambos, Augusto Azevedo também trabalhava em estúdio independente. Nas fontes que pesquisei, a grande recorrência de imagens fotográficas de Olavo Dutra e seus estúdios associados tornou merecida uma menção mais detida ao mesmo.

Olavo Dutra nasceu em 1898, em Caxias do Sul, cidade localizada na serra gaúcha. Até os 11 anos, residiu no município de Gravataí, região metropolitana de Porto Alegre. Chegou em Porto Alegre com 12 anos e foi trabalhar na Livraria do Globo. Interessando-se desde cedo pela fotografia, adquiriu uma máquina fotográfica e costumava realizar muitas imagens nos finais
5. Por mais que durante a investigação se buscassem informações sobre esse sócio do fotógrafo Olavo Dutra, não foi encontrada qualquer referência a ele. 
6. Foram o fotógrafo Jacob August Riis e seus companheiros Henry G. Piffard e Richard Hoe Lawrence os primeiros a utilizar este procedimento nos Estados Unidos. Piffard fez modificações na fórmula, que era extremamente perigosa, conseguindo uma mistura que queimava mais rapidamente que a fórmula anterior. Com tal procedimento, os três fotógrafos fotografaram os subúrbios de Nova Iorque à noite. O pó de magnésio foi utilizado para realizar fotografias noturnas até a década de 1920 , quando (entre 1925 e 1929) foram inventadas $e$ comercializadas as pri meiras lâmpadas de flash. NEWHAL, 1983, p. $132,229$.

7. GOIDANICH, 1979 Apud POSSAMAI, 2001, p. 81 . de semana. Quando a Livraria abriu o departamento fotográfico, em 1927, Olavo Dutra tornou-se fotógrafo profissional. Olavo Dutra teria sido o precursor da reportagem fotográfica em Porto Alegre, trabalhando com uma equipe de repórteres fotográficos, cuja produção era, então, enviada aos veículos da imprensa. A cobertura da Revolução de 1930 projetou nacionalmente o fotógrafo, que registrara a partida de Getúlio Vargas para o Rio de Janeiro. Nesta época, seu atelier, na rua dos Andradas, transformara-se em agência de distribuição, enviando as imagens fotográficas solicitadas pelos jornais de todo o país. Olavo Dutra foi o fotógrafo de personalidades políticas, de misses e de debutantes, além de ter sido o fotógrafo oficial de órgãos públicos. Foi autor de muitas vistas urbanas, inseridas nas suas reportagens fotográficas e publicadas em revistas de circulação local e nacional, como Revista do Globo, Mascara, Careta, O Malho e Fon-Fon. Olavo Dutra teria sido, ainda, o realizador da primeira vista noturna de Porto Alegre, quando eram raros os registros fotográficos feitos com pouca luminosidade. Tal intento foi alcançado graças à utilização do magnésio, produto importado da Alemanha, na época. A utilização da explosão de magnésio era utilizada desde 1887, permitindo o registro fotográfico em interiores com pouca ou nenhuma luz ${ }^{\circ}$. A façanha perigosa the valeu uma grande queimadura na mão. Apesar do incidente da estréia, o fotógrafo logo passou a dominar o uso do magnésio para a realização de imagens fotográficas, principalmente aquelas de casamentos.

Pela recorrência de imagens fotográficas de Olavo Dutra nas fontes que consultei, poder-se-ia considerar seu estúdio como um dos mais importantes da cidade após a morte de Virgílio Calegari e de Jacintho Ferrari. Tal afirmativa poderia ser corroborada não apenas pela grande quantidade de vistas urbanas, mas também pela presença de retratos de estúdio, publicados principalmente na Revista do Globo, o que demonstra seu estabelecimento ter tido, a partir da segunda metade da década de trinta, a preferência da clientela das camadas mais abastadas da sociedade. Olavo Dutra foi considerado, ao lado do fotógrafo Sioma Breitman, um dos melhores retratistas de Porto Alegre, por dar "um misterioso sopro de vida"7 ao semblante dos seus fotografados.

A presença de um único fotógrafo em arrabalde mais distante do centro da cidade demonstra que a fotografia produzida nos estúdios chegava muito lentamente aos porto-alegrenses pertencentes aos estratos sociais inferiores. Muito provavelmente porque os estúdios ainda se apresentavam como pouco acessíveis à maioria da população. Para um seleto grupo, entretanto, o fotógrafo de estúdio, nas décadas de 1920 e 1930, ainda se colocava como mediador relevante entre as pessoas e as imagens, mais precisamente entre os indivíduos e sua representação fotográfica.

O fotógrafo de estúdio não desapareceu no período pesquisado, embora tenha sofrido abalos com o processo de massificação da fotografia, acarretado principalmente pela disseminação das máquinas portáteis a partir do final do século XIX, assunto que retomarei adiante. Ao contrário, eles tiveram seu papel redimensionado, continuando a ser solicitados pela sociedade portoalegrense na elaboração de imagens de maior apuro artístico. $O$ fotógrafo 
passa, assim, a figurar entre os seres de inspiração subjetiva, numa aproximação da fotografia com a arte. "Talhado para sentir as emanações emocionantes da vida artística"8, o fotógrafo de estúdio, requisitado quase exclusivamente para a produção dos retratos, é alçado ao estatuto de artista, marcando a diferença estética entre as imagens fotográficas oriundas de seus pendores estéticos daquelas produzidas por qualquer indivíduo.

Se o fotógrafo de estúdio teve sua função e lugar social redimensionados no início do século XX, é possível perceber, por um lado, que esses profissionais procuraram alternativas para continuar viabilizando economicamente o seu negócio. Assim, além da produção de imagens de suas próprias autorias, muitos desses profissionais incluíram nos seus estabelecimentos a prestação de serviços fotográficos, tais como a realização de reproduções e ampliações, dirigindo seu alvo especificamente aos amadores. Por outro lado, tentavam diversificar os produtos fotográficos oferecidos à sua clientela. Alguns fotógrafos, por exemplo, confeccionavam retratos fotográficos sobre porcelana, destinados à ornamentação de túmulos e jazigos. Outros ofereciam pequenos presentes por ocasião da encomenda de imagens fotográficas. Ainda para vencer a concorrência, os estabelecimentos fotográficos ampliavam o horário de abertura, incluindo finais de semana e feriados.

Observa-se, também, que os fotógrafos passaram a realizar seu trabalho a domicílio, atendendo a expectativa dos consumidores de terem retratos artísticos produzidos em eventos esportivos, casamentos, bailes, banquetes e toda sorte de acontecimentos sociais. Olavo Dutra e Sioma Breitman deixaram inúmeros exemplos desses retratos, principalmente de noivas pertencentes às famílias porto-alegrenses, em uma época na qual o registro fotográfico tomava a dimensão de um ritual que se tornava parte do próprio casamento, vindo a tomar lugar ativamente na construção da memória sobre o episódio (LEITE, 200 1). Até 1917, a ausência do flash determinou que as fotografias de casamento realizadas anteriormente a essa data fossem todas externas ou que fossem feitas em estúdio adequadamente iluminado para tal finalidade. Assim, no final da década de 1920 já é possível encontrar "photographias a magnésio de casamentos" 9 , figurando como mais um produto oferecido pelos estúdios fotográficos, no momento em que os fotógrafos deixaram os cenários ali arquitetados, indo tirar fotografias nos mais diferentes locais de realização de tal evento social.

De outro ângulo, as fotografias de casamento e de outros eventos sociais, e a necessidade sentida pelas pessoas de obterem tais registros como parte do próprio acontecimento - como se a memória deste dependesse exclusivamente da imagem fotográfica -, podem ser atribuídas à disseminação da fotografia, intensificada nas primeiras décadas do século XX. Se as câmeras portáteis incluíam a imagem fotográfica na vida dos indivíduos, o registro tornavase uma necessidade premente da vida moderna. Nada mais natural que, nas ocasiões especiais, o fotógrafo profissional fosse chamado, então, para realizar tais imagens com qualidade e apuro artístico. Dessa forma, se, por um lado, o processo de massificação das imagens fotográficas acabou afetando diretamente 
10. Fabris (1991a, p. 17) identifica três etapas da relação entre fotografia e sociedade ao longo do século XIX: a primeira, entre 1839-1850, quando o interesse pelo novo invento restringia-se a um grupo seleto de indivíduos; a segunda, quando houve a descoberta do cartão de visita e a fotografia tornou-se acessível a muitos; a terceira, a partir de 1880, quando a fotografia se tornou fenômeno comercial, sem perder sua pretensão a arte seu métier, retirando-the consumidores, por outro, abriu-the novas frentes de trabalho, impingidas pelo novo hábito de incluir a própria representação visual na vida das pessoas.

Assim, a continuidade da maciça presença dos retratos, sejam esses elaborados ou não nos estúdios fotográficos, mostra que a imagem fotográfica individualizada continuou sendo um objeto de valor para a sociedade portoalegrense da época. Muito provavelmente o acesso à fotografia feita em qualquer ocasião não tenha eclipsado a relevância do retrato fotográfico elaborado pelo artista-fotógrafo, nem tampouco o papel social deste como agente legitimador dos papéis sociais dos indivíduos, através da produção de suas imagens. Ao contrário, encontra-se, nas décadas investigadas, a referência ao estúdio fotográfico tão elogiada quanto aquela ao seu respectivo fotógrafo. $\bigcirc$ atelier fotográfico ainda é um espaço freqüentado pelas famílias porto-alegrenses, e a ele creditava-se confiança e respeitabilidade. Porém, mais que o lugar onde se fazia apenas a produção de retratos, o estúdio fotográfico apresentava-se como espécie de centro cultural da cidade. No Salão da Photographia Dutra, por exemplo, um dos principais estabelecimentos da época, eram realizadas exposições não apenas fotográficas, mas de pinturas e outras obras artísticas. Esse tipo de atividade acabava por ampliar, sobremaneira, o público do atelier, que além dos fotografados incluía os freqüentadores dessas galerias de arte.

Dessa maneira, é importante ter em mente que o processo de banalização da fotografia não necessariamente levou à extinção dos estúdios fotográficos ou mesmo dos fotógrafos tradicionais. Como se viu, estes tiveram, sim, seu trabalho redimensionado a partir de novas necessidades colocadas pela massificação das imagens fotográficas. No caso dos retratos produzidos em estúdio, esses não apenas não perderam importância social como passaram a fazer parte de uma nova forma de circulação da imagem fotográfica, inexistente na virada do século: as revistas ilustradas. É assim que Olavo Dutra e mesmo Virgílio Calegari estão presentes com suas criações na Galeria Social da Revista do Globo, que expunha aos olhos de seus leitores os rostos e corpos de mademoiselles sorridentes, ultrapassando os limites do recôndito retrato produzido em décadas anteriores.

E nós fazemos o resto...

Ainda para dar conta da presença da fotografia em Porto Alegre nas décadas de 1920 e 1930, analisei a repercussão social, na cidade, da denominada massificação $0^{10}$ da fotografia, em curso a partir do final do século XIX, decorrente do advento das máquinas fotográficas portáteis. De fato, nas duas décadas investigadas, pude observar uma considerável penetração da fotografia na cidade, aferida por uma avalanche de anúncios publicitários, publicados nos jornais e revistas ilustradas, divulgando a comercialização dos aparelhos fotográficos portáteis. 
Desde a criação das pequenas câmeras Kodak, em 1888, ampliou-se consideravelmente o acesso à produção de imagens, que passou a ser franqueado a qualquer indivíduo. Você aperta o botão, nós fazemos o resto, era o slogan que a Eastman Kodak Company difundia em todo o mundo, como forma de divulgar as inovações técnicas de sua mais recente invenção. Tal facilidade parecia tornarse possível graças à criação de uma câmera que era comercializada contendo em seu interior um rolo de filme de 100 negativos, cuja revelação, e cópias, já estava incluída no custo do aparelho (NEWHAL, 1983). Da mesma maneira, a publicidade da Kodak \& Cia. - sede brasileira, localizada no Rio de Janeiro, da empresa norte-americana - tinha como objetivo difundir essa idéia de que o ato fotográfico era acessível a todos, graças às facilidades técnicas de manejo oferecidas pelos variados e inovadores modelos de sua câmera portátil, como pode ser visto em um dos tantos anúncios veiculados nos jornais:

\section{Kodak Autographica № $3^{\circ}$}

Este modelo teve grande aceitação entre os aficcionados da fotografia e é particularmente esturado (sic) pelos automobilistas e viajantes em geral.

Com ele obteem se fotografias de $8 \times 14$ cms $[\ldots]$, não obstante o seu peso leve e pequeno tamanho.

Em casa, a Kodak Autographica № 3 A, provou ser uma grande favorita e as crianças encontram nela um instrumento admirável de educação recreio e sã distração.

O seu manejo é extremamente simples e podem-se obter boas fotografias a primeira prova. Uma excursão sem uma Kodak perde uma grande parte do seu valor atrativo.

$[\ldots]$

KODAK BRASILEIRA LTD

$[\ldots]$

Se não é Eastman, não é Kodak"1.

A câmera portátil, desse modo, não apenas multiplicou o número de fotógrafos amadores, como possibilitou a penetração da possibilidade de criação de imagens fotográficas em todas as esferas do cotidiano dos indivíduos. Assim, em seus anúncios, a mesma Kodak \& Cia. reforçava as características de sua diminuta câmera, entre as quais se destacava a facilidade de manuseio e de transporte. Podendo ser levada no bolso do paletó e ser operada mesmo por uma criança, as portáteis tornavam a produção de imagens fotográficas ato corriqueiro e realizável em qualquer ocasião e momento. Nas viagens por mar ou por terra, ou nos passeios diários, a Kodak deixava ao alcance de todos as lembranças dos acontecimentos triviais ou especiais da vida, que assumiam a forma de imagens fotográficas.

É importante não perder de vista que o advento da câmera fotográfica portátil, bem como o da fotografia nos seus primórdios, esteve inserido em um processo mais amplo de modernização ${ }^{12}$, que estendeu seu alcance à vida cotidiana dos indivíduos. Dessa forma, a aceleração da vida psíquica e mental e a rápida penetração da tecnologia em todas as esferas humanas poderiam ser consideradas características da vida moderna, que incluíam, também, o domínio da percepção visual (PHILLIPS, 1994). Assim, no século XIX, se Daguerre - ao criar o Diorama ${ }^{13}$ e também suas imagens mágicas - estava buscando uma forma
11. KODAK autographica $\mathrm{N}^{\mathrm{o}} 3^{\circ}$ Correio do Povo, Porto Alegre, p. 7, 27 set. 1922. Anúncio publicitário.

12. Berman (1988, p. 16) conceitua modernização como sendo um processo que englobaria, entre outros aspectos, a industrialização, o desenvolvimento tecnológico, o crescimento urbano, a explosão demográfica, $o$ desenvolvimento dos sistemas de comunicação de massa.

13. FABRIS, 1991b. O Diorama de Daguerre era uma vista geral, em que a iluminação do quadro era móvel, criando uma ilusão óptica de tridimensionalidade. 
14. Sobre o fotoamadorismo em Porto Alegre, ver SANTOS, 1997.Anteriormente à massificação da fotografia, o autor identifica duas fases do fotoamadorismo: a primeira tem interesses científicos no ato fotográfico, enquanto a segunda, capitaneada por uma minoria privilegiada, busca características artísticas para suas imagens fotográfi cas. Esta última modalidade também foi denominada fotoclubismo. de melhor representar visualmente a realidade, o século XX acelerou esse processo de busca com a substituição rápida de novos engenhos por outros cada vez mais aperfeiçoados tecnologicamente. A fotografia ganhou, dessa maneira, espaço na vida cotidiana, por possibilitar apreender o mundo moderno, cada vez mais complexo e distante do indivíduo. A câmera portátil facilitou ainda mais esse processo de construção de representações visuais do mundo e das coisas, permitindo que qualquer pessoa fosse um fabricante de imagens fotográficas.

No entanto, no caso de Porto Alegre, considerei muito complicado aferir com precisão a penetração da fotografia entre sua população a partir unicamente dos registros dos anúncios publicitários da principal empresa fabricante de um produto, como é o caso da câmera portátil Kodak. Melhor seria pensar esses textos - ufanistas em relação ao produto a ser vendido - como idéias a serem também difundidas, contribuindo para introduzir um novo artefato tecnológico na vida e nos hábitos dos indivíduos. Se, por um lado, tratava-se de adquirir o aparelho fotográfico e passar a produzir imagens - antes elaboradas apenas por um artista profissional ou pelos adeptos do fotoamadorismo ${ }^{14}$, presente em Porto Alegre desde o final do século XIX -, por outro, tratava-se de uma nova dimensão dada à própria imagem fotográfica, agora não necessariamente envolta no glamour dos estúdios fotográficos, lugar que fazia do fotografar-se ato simbólico revestido de especial valor, principalmente para as camadas superiores da sociedade, como mostrei anteriormente.

Mas quem e quantas pessoas realmente adquiriam os tais aparelhos fotográficos? A julgar pelo número de anúncios publicados nos jornais e revistas, pode-se pensar que a mensagem publicitária tenha sido recebida pelos consumidores e, conseqüentemente, esse produto tenha adentrado os lares porto-alegrenses. Ou poderia imaginar-se uma publicidade maciça do fabricante, a fim, justamente, de introduzir a mais recente invenção. Assim, as informações disponíveis nas fontes pesquisadas fornecem apenas pistas relativas ao alcance do consumo da fotografia em Porto Alegre, através dos dados relacionados à presença nas residências portoalegrenses do aparelho que possibilita sua produção.

Nessa direção, os anúncios de leilões (de imóveis, mobiliário, veículos, equipamentos e aparelhos) realizados em várias casas da cidade mostram a presença do aparelho fotográfico nas residências dos porto-alegrenses nas décadas pesquisadas. Esses leilões eram realizados por proprietários que, por algum motivo, estivessem mudando seu endereço residencial ou comercial dentro da própria capital ou para outra cidade. Assim, eram objeto de leilão, além do imóvel, todo o mobiliário da residência ou casa comercial, juntamente com equipamentos, aparelhos eletrodomésticos e veículos. $\bigcirc$ leiloeiro anunciava a referida comercialização, informando, na maioria dos casos, que o leilão seria realizado na própria residência do proprietário. Geralmente estas estavam localizadas no centro da cidade ou nos bairros nobres próximos a ele. Além disso, o aparelho fotográfico vinha descrito entre o mobiliário e aparelhos pertencentes à sala de jantar. Dessa última informação, pode-se conjeturar ser ele considerado pela família um signo de diferenciação social. Estando presente na sala de jantar, o aparelho poderia ser mostrado aos visitantes mais íntimos 
da família, para a qual era assegurada uma imagem não apenas de poder econômico (pelo fato de esta ter podido adquiri-lo), mas também de modernidade (por ela possuir um engenho inovador desse porte). $\bigcirc$ anúncio abaixo é um dos tantos exemplos entre os que podem ser citados:

\title{
LEILÃO
}

FINOS MOVEIS - ELEGANTES CONJUNTOS PARA GABINETES E DORMITORIOS - EXCELLENTE "CHAISE LONGUE" - FINISSIMA VITRINE PARA SALA DE VISITAS - LUXUOSOS TAPETES, LINDO JOGO PARAVENT, EM LAQUET - SUPERIOR CARRO PARA CREANÇA - MAGNIFICA MACHINA PARA BORDAR E COSTURAR "SINGER" - PERFEITA MACHINA PHOTOGRAPHICA KODACK AUTOGRAPHICA, 8 X 14 - QUADROS - ADORNOS - OBJECTOS DE MESA - FOGÃO EM FERRO №O - UTENSILIOS DE COSINHA

Hoje, as $3^{\prime}$ horas

rua Jeronymo Coelho, n. 37 (entre Bragança e avenida Borges de Medeiros) - Bond De

Autorisado pelo $11 \mathrm{~m}^{\circ}$. Sr. IVAN ASTOR, que segue para a Europa

\author{
Leiloeiro \\ VICTORINO PINTO \\ succ. de Vicente Pinto \\ vendera todos os finos moveis que figuram no
}

\section{CATALOGO}

$[\ldots]$

SALA DE JANTAR - Moderno buffet de couro, peça muito bem trabalhada, com marmores e crystaes; gracioso trinchante de modernissimo feitio, com crystaes facetados; excellente terno estofado em brocatel; cadeiras, fabricação "Gerdau"; superior mesa elástica, de louro, para sala de jantar; magnificas e finas columnas de louro, com metaes; luxuoso panno de mesa; perfeita e boa machina photographica "Kodack" autographica, tamanho $8 \times 14$; "Ceia de Christo" em custosa moldura; finissimo tapete de velludo, de grande tamanho; mesa auxiliar de louro, desarmavel; infinidade de objectos de mesa, dentre os quaes se destacam os seguintes: porta-copos com guarnição de metal; chicaras de porcellana japoneza para café; galheteiros, licoreiros, saladeiras, bons talheres, pratos, terrinas, sopeiras, centro de mesa com metaes; fruteiras, pratos para gelados, vidros para balas, copos para agua e vinho; calices para licor, etc.

$[\ldots]^{15}$

Esses anúncios estavam relacionados a propriedades pertencentes, na sua larga maioria, às famílias mais ricas da sociedade porto-alegrense. Assim, em vários deles foi encontrada, entre os aparelhos colocados à venda, a presença da "máquina fotográfica" ou do "aparelho fotográfico", em alguns casos com a devida identificação da marca do fabricante. Pode-se, desta forma, afirmar que a máquina fotográfica estava presente nos lares porto-alegrenses, pelo menos entre aqueles pertencentes às camadas mais abastadas e aos setores médios. É importante notar que o aparelho fotográfico figurava ao lado de outros aparelhos, como rádio de válvulas da marca RCA Victor, máquina de coser e bordar da marca Singer, máquina de escrever, eletrola, aspirador de pó e enceradeira. 
16. BRINDES de Mascara Mascara, Porto Alegre, $\mathrm{n}$. 1, [ 1920]. Não paginado.

17. MACHINA photographica com lente Zeiss Correio do Povo, Porto Alegre, p. 11, $15 \mathrm{dez}$ 1926. Anúncio publicitário. Considerei que, como forma de atrair compradores para a sua máquina usada, $o$ anunciante supervalorizou o preço de um aparelho novo.

18. A fotografia colorida surgiu a partir da invenção do filme colorido $k o-$ dachrome, em 1937.Antes disso, eram feitas pinturas e retoques sobre a fotografia em preto branco, a fim de se obter coloração na imagem. Datam de 1850 as primeiras tentativas de produzir cor automaticamente nas imagens fotográficas, sendo que, em 1860, alcançou-se o mecanismo para obtenção da fotografia colorida através da projeção de três lâminas transparentes e de cores diferentes sobre um negativo. Cf. NEWHAL, 1983
Todos eles produtos bastante recorrentes na publicidade do início do século XX e apresentados como ícones distintivos da modernidade urbana, indispensáveis ao conforto da vida doméstica.

acesso restrito aos aparelhos fotográficos pode ser aferido, ainda, pelo valor de comercialização dos mesmos. Tratando-se de um produto importado, pode-se imaginar ser seu valor ainda bastante elevado para a maioria da população brasileira. Em 1920, a revista Mascara ofereceu vários brindes aos seus assinantes que saldassem suas dívidas; entre eles encontrava-se um aparelho fotográfico, cujo valor era aferido em $200 \$ 000$, um fino quadro com direito a uma fotografia colorida (no valor de $300 \$ 000$ ), uma elegante fatiota de casimira (no valor de $250 \$ 000$ ) e um aparelho de cristal Bacarat com 15 peças (no valor de $500 \$ 000)^{16}$. Nessa mesma década, foi localizado anúncio oferecendo, pelo valor de 150\$000, um aparelho fotográfico já usado, e informando que um aparelho novo estaria custando aproximadamente 1:250\$000 ${ }^{17}$.

Esses valores demonstram que o aparelho fotográfico era objeto de elevado valor, assim como o era a fotografia colorida, recém-conhecida, cujo valor poderia ser superior, inclusive, ao próprio aparelho. Esse preço cobrado por uma fotografia colorida justificava-se, pois a novidade descortinava para os leitores visuais um mundo que, até então, era passível de apreciação apenas em imagens fotográficas em preto e branco ${ }^{18}$.

Pistas sobre o consumo da fotografia em Porto Alegre podem, ainda, ser deduzidas a partir da presença das casas que comercializavam produtos fotográficos. Nas décadas pesquisadas, encontrei a referência a estabelecimentos comerciais localizados na rua dos Andradas - na época, principal via comercial de Porto Alegre -, onde também se localizavam os maiores ateliers fotográficos, conforme mostrei anteriormente. As lojas, assim, vieram localizar-se também no centro da cidade, bairro não apenas de maior incidência de estúdios fotográficos, mas ponto de maior afluência dos consumidores na cidade.

As casas comerciais - como Casa Senior, Casa de Armas João Bergman, A. Brockman \& Cia., Bazar Abelheira, Casa Masson, Livraria do Globo -, em sua grande maioria, não se dedicavam exclusivamente à comercialização de produtos fotográficos. Freqüentemente os anúncios publicitários de algumas dessas lojas trazem, ao lado dos materiais e aparelhos destinados à arte fotográfica, artigos dentários ou cirúrgicos e instalações para laboratórios químicos e bacteriológicos, por ser a casa especializada na importação de todos esses tipos de produtos. E é comum a loja ter uma denominação pouco relacionada ao métier, mantendo, porém, uma seção fotográfica responsável pela venda desse tipo de artigo.

A Casa Senior, de propriedade de Alfred Dennin, foi o estabelecimento comercial de maior recorrência nos anúncios localizados nos jornais e revistas consultados. Desde o início dos anos 1920, a casa apresentava uma ampla variedade de artigos destinados ao ofício fotográfico, tanto de profissionais quanto de amadores. Entre os produtos que oferecia, encontravam-se: aparelhos fotográficos das marcas Zeiss, Goerz, Ica, Glunz, Ernemann, Goltzz e Breutmann, Kodak, Ansco; os papéis Mimosa Velotyp, Mimosa Aurotyp, Mimosa Celloidin, 
Satrap, Lumière, Kodak, Ansco; chapas e produtos químicos Agfa, Perutz, Hauff, Kodak, Lumière, Wratten, Ilford; lentes Zeiss, Goerz, Rodenstock, Busch (Bausch?), Voigtlaender, Kodak. Além dessa gama de marcas de produtos fotográficos oferecidos, ali ainda podiam ser adquiridos álbuns e cartões para fotografia, bacias de vidro, louça ou ferro esmaltado, mesas para retoque e para colorir, prensas para copiar e tripés de madeira ou latão ${ }^{19}$. Nos anúncios da Casa Senior era comum a chamada principal estar direcionada para o consumo do aparelho fotográfico, considerado muito útil e ótimo presente, estimulando, dessa forma, novos consumidores da fotografia e da produção de imagens ${ }^{20}$. Além da venda de artigos fotográficos, essas casas ofereciam oficina de consertos de aparelhos fotográficos, revelação de filmes e chapas, realização de cópias e ampliações em papéis ou cartões postais, além de oferecer o ensino fotográfico gratuito.

Nos anúncios publicitários, entre os produtos de maior destaque, figurava, sem sombra de dúvida, o aparelho fotográfico. A Kodak Brasileira Ltda, como já observado, inundava os jornais e revistas brasileiros, e provavelmente do mundo todo, com a publicidade sistemática dos variados modelos das máquinas portáteis colocadas à disposição dos consumidores. Em concorrência com esta, também foi encontrada referência à máquina Super Ikonta, da marca Zeiss. Ao lado dos aparelhos, os filmes fotográficos também apresentavam uma publicidade recorrente, principalmente os dos fabricantes Agfa, Zeiss e Kodak. Além dos equipamentos e materiais destinados à produção fotográfica, eram comercializadas as próprias imagens fotográficas, principalmente através de cartões postais, de retratos photo-films, de retratos no tamanho mignon, de retratos no sistema simil esmalte e, finalmente, de álbuns fotográficos.

Conforme mostrei antes, o aparelho fotográfico ainda apresentava elevado valor de comercialização na década de 1920, restringindo sua aquisição às camadas mais favorecidas da sociedade. Convém esclarecer que tal afirmação está baseada em um único valor localizado, sem, no entanto, serem levadas em consideração as características da máquina fotográfica, cujas opções de modelos deveriam determinar, com certeza, o seu valor. Na década de 1930, no entanto, foi localizado anúncio oferecendo aparelhos fotográficos desde o valor de $22 \$ 000^{21}$, cerca de dez por cento do valor de comercialização localizado na década anterior, o que indica ter esse se tornado substancialmente mais acessível com o passar dos anos. No mesmo período, a Casa Masson parcelava o pagamento do aparelho, com prestações entre $7 \$ 500$ e $22 \$ 000$ mensais ${ }^{22}$, dado esse que, certamente, tornava ainda mais facilitada a sua compra.

Assim, os valores de comercialização dos aparelhos fotográficos localizados nas fontes consultadas foram os seguintes:
19. CASA Senior. Mascara, Porto Alegre, n. 30, [s.p ], 1920.

20. UM PRESENTE muito útil é um apparelho photographico. A Estância, PortoAlegre, n. 10,p.305, dez. 1925/jan. 1926 Anúncio publicitário; $\mathrm{O}$ MELHOR presente para a festa de Natal é um apparelho photographico. $R e$ vista do Globo, PortoAlegre, n. 23, 1930.Anúncio publicitário não paginado;APPARELHOS photographicos. Revista do Globo,PortoAlegre,n. 16 , 1931.Anúncio publicitário não paginado.

21.A CASA de armas João Bergman oferece para natal e ano bom. Revista do Globo,PortoAlegre,n.24, p. 90, 1934.Anúncio publicitário.

22. Valores retirados, respectivamente, de: MASSON. Correio do Povo, Porto Alegre, p. 8, 12 dez. 1935; PRESENTES da Casa Masson.Correio do Povo, Porto Alegre, p. 7, 28 nov. 1935.Anúncio publicitário

$\begin{array}{cc}\text { Década } 1920 & \text { Década } 1930 \\ 200 \$ 000 & 22 \$ 000 \\ 150 \$ 000 & 46 \$ 000\end{array}$


23. Estes valores foram retirados, respectivamente, de: FOTO-FILMS. Correio do Povo, Porto Alegre, $\mathrm{p}$ 7,5 agrupamento. 1922 SENHORA alemã, tendo se associado e assumido a gerência da Photo Rembrandt oferece trabalhos artísticos a preços razoá veis. Correio do Povo, Porto Alegre, p. 7, $11 \mathrm{fev}$ 1926. Anúncio publicitário; Id.; PHOTO Electrica Correio do Povo, Porto Alegre, p. 6, 26 ago. 1926 Anúncio publicitário; Id.

24. Considera-se que "postais" refira-se às vistas urbanas.
A partir dessas informações, pude verificar que, por parte dos setores médios porto-alegrenses, foi ampliado o acesso aos aparelhos fotográficos no decorrer das duas décadas investigadas. Também corrobora essa hipótese a presença dos estabelecimentos que faziam a comercialização de outros produtos destinados, principalmente, aos amadores. Entretanto, há que ser relativizada a massificação da fotografia, no sentido de que, certamente, serão ainda necessárias várias décadas para ela atingir amplas parcelas da população.

Assim (e mesmo sendo ainda acessível a grupos restritos), a presença da fotografia em Porto Alegre, aferida a partir dos elementos que levantei, indica a sintonia da cidade com as inovações tecnológicas, que eram consideradas como marcas distintivas de um determinado imaginário. Então, para as elites burguesas e republicanas, compartilhar o novo hábito de fotografar-se, ser fotografado e - talvez mais importante - ser visto ao fotografar e ser visto ao ser fotografado em ocasiões mundanas das mais diversas, portando uma kodak portátil, certamente era mais um sinal distintivo a acrescentar no rol de elementos de uma visualidade que definia o que era ser moderno, o que era uma cidade também moderna e como era viver nela, consoante o imaginário da época.

A propagação das vistas urbanas

Tentei realizar a mesma análise dos aparelhos fotográficos para as imagens fotográficas, verificando, através das informações sobre seus valores, o acesso da população porto-alegrense a elas. As imagens fotográficas comercializadas em Porto Alegre no período da década de 1920 apresentavam os seguintes valores ${ }^{23}$ :

Uma dúzia de retratos photo-films

$1 \$ 500$

Uma dúzia de postais ${ }^{24}$

$8 \$ 000$

Uma dúzia de phoło mignon

$3 \$ 000$

Uma dúzia de postais

desde $10 \$ 000$

Uma dúzia de photo-films com semil-esmalte

$15 \$ 000$

Certamente esses valores eram bem mais alvissareiros do que o dos retratos realizados em estúdio no decorrer do século XIX, que eram artigo artístico adquirido tão somente pelos "endinheirados da época" (DAMASCENO, 1974, p. 36).

Tomando os valores de comercialização dos álbuns fotográficos encontrados na década de 1930, é possível comparar com as cifras referentes às vistas urbanas comercializadas na década de 1920. Nota-se uma substancial diminuição dos valores cobrados pelas imagens fotográficas, como mostro a seguir: 
Essa subtração é ainda mais notória se for levado em conta que os postais da primeira década eram vendidos de forma avulsa, enquanto o álbum, além de reunir mais de uma centena de vistas da cidade, recebia o formato de uma publicação de qualidade, conforme o próprio anúncio prometia. Assim, é possível afirmar que, ao longo do período pesquisado, as imagens fotográficas comercializadas foram se tornando mais acessíveis para os seus consumidores visuais, principalmente as imagens de vistas urbanas. De fato, conforme observa Solange Ferraz de Lima, a partir da segunda metade do século XIX houve um barateamento das vistas urbanas, devido ao processo de produção industrial em série e em larga escala, bem como pela introdução das atividades editorial e gráfica. Ocorreu, como se vê, uma acelerada disseminação das vistas urbanas, que passaram a atingir maiores parcelas da sociedade, sendo utilizadas em correspondências pessoais e na divulgação exterior das imagens do Brasil (LIMA, 19911.

Desse modo, as vistas urbanas foram responsáveis pela difusão de novos padrões visuais urbanos de acordo com o ideário da burguesia. Não apenas divulgaram as transformações pelas quais passavam as cidades brasileiras, como foram responsáveis pela construção de um imaginário visual urbano ligado à modernidade. Em Porto Alegre, desde o final do século XIX, as vistas urbanas tomaram parte ativa na construção de representações visuais da cidade. A propagação das imagens fotográficas reunidas nos álbuns dos Irmãos Ferrari e, posteriormente, de Virgílio Calegari contribuiu para a divulgação de um imaginário urbano calcado na visualidade fotográfica, abrindo as portas para imagens apologéticas do ideário urbano moderno, amplamente disseminado no momento em que, a partir da década de 1920, Porto Alegre passava a viver transformações mais profundas do seu desenho urbano.

Para essa divulgação, contribuíram as revistas ilustradas publicadas em Porto Alegre, nas primeiras décadas do século XX, como Kodak, Kosmos, Mascara e, posteriormente, Revista do Globo. As vistas urbanas ocupavam parte substancial das páginas desses semanários, podendo estar reunidas em matérias especiais sobre os melhoramentos urbanos em curso. As revistas dedicavam considerável espaço às transformações urbanas, fornecendo informações detalhadas sobre as obras em andamento, bem como sobre aquelas ainda por vir, ilustrando fartamente, com imagens fotográficas, o seu texto de tom elogioso. Dessa forma, as vistas da cidade ganharam, nas revistas, um espaço de circulação que potencializou o poder de difusão das representações ligadas à modernidade urbana, através das imagens das reformas levadas a efeito e das novas sociabilidades citadinas.

Para a elaboração desse imaginário disseminado pelas revistas ilustradas através das vistas urbanas, entravam na cena fotografada não apenas os referentes considerados fielmente registrados pela câmera fotográfica, traços 
25.A NOSSA capital. Revista do Globo, PortoAlegre, n. 12, 1932, p. 24-25.

26. Santos (1997), ao pesquisar sobre o fotógrafo Virgílio Calegari, encontrou entre seus pertences um álbum de fotografias da cidade de Nova Iorque, demonstrando que esta metrópole fazia parte do imaginário visual daquele artista. indiscutíveis da modernidade de Porto Alegre: também poderiam ser utilizados artifícios para melhor representar as idéias a serem difundidas. A imagem de uma mélange fantástica publicada nas páginas centrais da Revista do Globo ${ }^{25}$, composta através da colagem de fotos dos edifícios de altura mais elevada de Porto Alegre, é exemplar da representação visual de cidade divulgada pela revista e por suas imagens fotográficas. Nessa fotomontagem, Porto Alegre adquire feições semelhantes à da cidade de São Paulo, ou mesmo de Nova lorque, ao reunir em um único espaço diversas edificações de altura elevada que se encontravam distribuídas pela cidade. Esta eloqüente imagem merece algumas considerações.

Primeiramente, a utilização de um recurso estético como a fotomontagem, bastante divulgada na década de 1920, demonstra a ałualização - da fotografia e das revistas ilustradas em Porto Alegre - com os recursos técnicos presentes em outras partes do mundo ${ }^{26}$. Como mostrou Phillips, esse artifício foi amplamente utilizado pelos fotógrafos, como forma de representar as cidades, a partir de uma nova percepção visual suscitada pelos novos meios tecnológicos recém-inventados. A cidade de feições colossais e múltiplas e o ritmo imposto à vida das pessoas pelas inúmeras máquinas e procedimentos mecânicos (como o automóvel, os trens, o telefone, e mesmo a câmera fotográfica) tornaram a imagem fotográfica um modo de apreender e de representar visualmente esta nova e complexa realidade. Assim, as fotomontagens dos anos 1920 pretendiam associar a cidade moderna a uma ampla montagem, na qual espaços e ritmos descontínuos eram justapostos sem encontrar referente na cidade concreta, privilegiando uma representação visual que percebia o urbano como uma rede de fragmentos dispersos (PHILLIPS, 1994).

Muito provavelmente essa imagem encontrada na Revista do Globo seja uma exceção no panorama fotográfico da Porto Alegre daquele contexto, no sentido da utilização do artifício da fotomontagem para representar a cidade. Helovise Costa, ao debruçar-se sobre a fotografia moderna brasileira em São Paulo, pôde perceber que, no advento da nossa modernidade, nas artes plásticas, não foi dado lugar à fotografia (COSTA, 1995). Se o embate entre tecnologia e racionalização estava presente nas obras de modernistas como Tarsila do Amaral (AVELINO, 1999), por exemplo, a fotografia ainda se via emaranhada no debate que tentava situá-la entre arte sensível e cópia fiel da realidade, presente desde o século XIX. É apenas após a Segunda Grande Guerra que um "novo olhar" será proposto pelos fotógrafos da Escola Paulista. Nessas imagens, São Paulo é representada a partir de automóveis, estações de trens, placas de trânsito, túneis; em composições assimétricas e fotomontagens que privilegiavam aspectos como a fragmentação, a velocidade, o anonimato e a não-identificação de lugares daquela cidade (COSTA, 1995). Em Porto Alegre, as fotomontagens estarão presentes de forma mais marcante após a década de 1940, no trabalho de João Alberto Fonseca da Silva, que atuava ao lado de arquitetos, sobrepondo ao tecido urbano novos projetos em criação.

Feita esta ressalva, no entanto, essa colagem fotográfica tentava difundir a idéia de que, no seu espaço urbano, principalmente no centro da 
cidade, Porto Alegre reunia edificações de mesmo gabarito daquelas presentes em outras metrópoles. E, finalmente, criava uma imagem urbana sugerida como ideal para a cidade. Ao reunir todas as edificações num único espaço, a montagem reforçava a idéia de que estes ícones arquitetônicos eram referências do moderno no espaço urbano, e que Porto Alegre, desejada moderna por sua sociedade, já os possuía; mas que, mesmo assim, ainda necessitava multiplicálos para chegar a assemelhar-se a outras metrópoles do país ou do mundo.

Assim, as vistas urbanas, ao adquirirem grande disseminação entre os porto-alegrenses através das revistas ilustradas, contribuíram para a construção de representações da cidade moderna. Fizeram isso através da valorização de aspectos e lugares da cidade que reforçavam as características consideradas referenciais de modernidade, como a arquitetura dos altos edifícios, os novos espaços de sociabilidade, as novas vias de circulação, os melhoramentos urbanos, os novos serviços.

Tais imagens potencializaram a sua capacidade de difundir representações sobre a cidade, tornando-se veiculadoras e propagadoras do imaginário de modernidade urbana. Dessa forma, ao lado das transformações pelas quais Porto Alegre passava, a fotografia e as vistas foram parte da dinâmica de estruturação de uma cidade moderna, na qual a visualidade tinha um papel fundamental. Não era necessário apenas redesenhar o espaço segundo os novos parâmetros, mas também criar uma imagem que tornasse presente, ainda que no plano visual, a cidade moderna.

Nesse sentido, a fotografia será parceira inestimável, pois a ela será dado o poder de construir, da cidade, uma imagem considerada como o seu registro fidedigno. Essa atribuição, dada ao registro fotográfico, de ser profundamente semelhante ao referente fotografado tornou as vistas urbanas extremamente capazes de criar imagens visuais que corresponderam às expectativas, desejos e interesses dos sujeitos modernos, sejam eles os fotógrafos, os editores dos álbuns fotográficos ou mesmo os leitores visuais da cidade.

Desde o seu surgimento, a fotografia foi considerada como espelho da realidade, devido às características mecânicas e físico-químicas de produção do registro fotográfico, feito a partir do reflexo da luz que incide sobre determinado objeto e penetra no dispositivo ótico, conferindo extraordinária verossimilhança à imagem fotográfica em relação ao seu referente. Como ressalta Arlindo Machado, no entanto, a fotografia foi considerada como capaz de reproduzir o real, porque, ao se tratar do seu dispositivo tecnológico, opera-se com concepções de mimese e objetividade criadas a partir das características do ato fotográfico (MACHADO, 1984).

Por esse aspecto, desde os seus primórdios, foi conferida à fotografia a capacidade de registro fiel e privilegiado da realidade; e, neste sentido, seu aspecto documental. Dessa forma, esteve a fotografia vinculada à capacidade de retenção e registro da memória, pois se constituía no meio mais apropriado de guardar os elementos visuais das sociedades ao longo dos anos. À fotografia, assim, foi dada a responsabilidade e a tarefa de registrar o mundo e as coisas, fixando, na imutabilidade de um instante, fragmentos da realidade perdidos 
27. O debate em torno da crítica à objetividade da fotografia e às concepções desta como transformação da realidade podem ser encontrados em DUBOIS, 1992; KOSSOY, 2002b; e MACHADO 1984 . para sempre, não fosse essa possibilidade mágica de conter o decurso inexorável do tempo.

Entretanto, exame minucioso do processo fotográfico leva a questionar a possibilidade de registro fidedigno do referente, tendo em vista outras características do ato fotográfico, que vão do domínio estético e técnico até a clivagem ideológica de quem opera a máquina. Nesse caso, abandona-se a concepção da fotografia como duplicação do real, passando esta a ser considerada como transformação do real, produzida pelo ato fołográfico ${ }^{27}$. Entra em cena o olhar do autor, o fotógrafo, e suas múltiplas escolhas ao efetuar um recorte na realidade para ser perenizado num determinado instante. Nessa concepção, a fotografia constitui-se em fragmento que recorta o real de acordo com o quadro delimitado na imagem fotográfica, excluindo dele um sem número de elementos que fizeram parte da realidade apenas naquele momento em que se apertou o botão. As escolhas do fotógrafo podem ser de ordem estética, técnica, temática e podem estar intimamente vinculadas às suas concepções culturais, às suas condições sociais ou às suas idéias políiticas. Assim, embora na Porto Alegre das décadas estudadas possam ser localizadas fotomontagens circulando nas revistas ilustradas, a fotografia será considerada primordialmente como engenho mecânico mágico, capaz de reproduzir, em imagem visual fiel, não apenas o semblante dos indivíduos, mas também as novas configurações urbanas.

Nesse sentido, posso afirmar que a fotografia teve uma presença de destaque em Porto Alegre nas décadas de vinte e trinta do século XX. Essa presença é comprovada pelos vários estúdios fotográficos e estabelecimentos localizados, na sua franca maioria, no centro da cidade; pela recorrência (nos jornais e revistas publicados) de anúncios publicitários de aparelhos, de filmes e de materiais fotográficos; pelo consumo do aparelho fotográfico por parte das camadas mais abastadas e setores médios; pela circulação de imagens fotográficas, seja através da comercialização de vistas, da elaboração dos retratos de estúdio ou da publicação maciça de imagens fotográficas nas revistas ilustradas.

Nesse período a cidade passava por profundas transformações em seu espaço urbano, que adquiria feições em consonância com o ideal e o projeto de uma cidade moderna, propostos a partir de um plano urbanístico. A fotografia, nesse sentido, foi encarada como engenho da modernidade, signo da inovação tecnológica em curso em várias partes do mundo. Sua presença no espaço urbano de Porto Alegre, através da localização dos estúdios fotográficos e casas comerciais, era mais um elemento a contribuir para a divulgação de um imaginário de cidade atualizada com seu tempo e com as inovações tecnológicas por ele criadas.

Se a necessidade de representação visual foi intensificada a partir do advento da fotografia, o seu processo de massificação transformou essa necessidade em um imperativo da vida moderna, meio através do qual pode ser assegurada a apreensão de si e do mundo. Assim sendo, as imagens fotográficas, agora produzidas por qualquer indivíduo que detivesse uma portátil, 
eram os veículos não apenas da possibilidade de representar as coisas, mas de apreender fragmentos do turbilhão urbano moderno.

Assim, a fotografia em Porto Alegre está intimamente ligada à construção e à veiculação do imaginário de modernidade. Entre outros aspectos, ser moderno, para os porto-alegrenses das décadas de 1920 e 1930, é freqüentar o estúdio fotográfico de renomado artista e ter seu retrato assinado por ele. Ser moderno é figurar entre os "retratados" das revistas ilustradas. Ser moderno é possuir entre seus pertences domésticos um aparelho fotográfico de marca estrangeira, ao lado de outros eletrodomésticos e aparelhos apontados pela publicidade como imprescindíveis para a vida moderna. Ser moderno é utilizar este mesmo aparelho em ocasiões as mais diversas, podendo registrar os acontecimentos cotidianos ou especiais. Ser moderno é, pois, morar em uma cidade moderna. Cidade esta que pode ser visualizada através de suas imagens fotográficas, vistas urbanas avulsas ou reunidas nos álbuns fotográficos adquiridos para presentear um amigo; ou para ser estrategicamente colocado na sala de jantar, para que possa ser apreciado em reuniões familiares ou em visitas importantes.

Nesse sentido, as imagens fotográficas foram consideradas como meios através dos quais o mundo pode ser representado de acordo com o desejo da sociedade que o criou. As vistas urbanas, especialmente, representaram uma cidade de acordo com o desejo de seus habitantes, ou pelo menos de uma parcela deles. Ao tornar possível que esta cidade se transforme em imagem, ou seja passível de ser visualizada com extrema aproximação com a realidade, as imagens fotográficas acabaram por veicular um imaginário de cidade em consonância com o ideal de modernidade.

\section{REFERÊNCIAS}

ALVES, H. R. A fotografia em Porto Alegre: o século XIX. In:ACHUTTI, Eduardo Robinson (Org.). Ensaios (sobre o) fotográfico. Porto Alegre: Unidade, 1998. p. 9-21.

AVELINO,Y. et al. Arte urbana e reminiscências rurais na obra deTarsila do Amaral.Projeto História, São Paulo, n. 19, p. 97-119, nov. 1999.

BAKOS, M. M. Porto Alegre e seus eternos intendentes. Porto Alegre: Edipucrs, 1996.

BELLO, H. E. O ecletismo e a imagem da cidade. 1997. 160 f. Dissertação (Mestrado em Planejamento Urbano e Regional)-Programa de Pós-Graduação em Planejamento Urbano e Regional, Faculdade de Arquitetura, Universidade Federal do Rio Grande do Sul, Porto Alegre, 1997.

BERMAN, M. Tudo que é sólido desmancha no ar: a aventura da modernidade. São Paulo: Companhia das Letras, 1988. 
COSTA, H. Fragmentos urbanos: a imagem da cidade na fotografia moderna brasileira dos anos 50. In: CONGRESSO BRASILEIRO DE HISTÓRIA DA ARTE, 5., 1995, Anais... São Paulo. Escola de Comunicação e Artes, Universidade de São Paulo, 1995. p. 241-244.

COSTA, H.; RODRIGUES, R. A fotografia moderna no Brasil. São Paulo: Cosac Naify, 2004.

DAMASCENO, A. Artes plásticas no Rio Grande do Sul (1755-1900): contribuição para o estudo do processo cultural sul-riograndense. Porto Alegre: Globo, 1971.

.Colóquios com a minha cidade. Porto Alegre: Prefeitura Municipal de Porto Alegre, 1974.

DOBERSTEIN, A. W. Porto Alegre, 1900-1920: estatuária e ideologia. Porto Alegre: Secretaria Municipal da Cultura, 1992.

DUBOIS, P. O acto fotográfico. Lisboa:Vega, 1992.

FABRIS,A. (Org.). Fotografia: usos e funções no séc. XIX. São Paulo: Edusp, 1991a.

O circuito social da fotografia: estudo de caso I. In: (Org.). Fotografia: usos e funções no séc. XIX. São Paulo: Edusp, 1991b. p. 39-57.

KOSSOY, B. Dicionário bistórico-fotográfico brasileiro: fotógrafos e ofício da fotografia no Brasil (1833-1910). São Paulo: Instituto Moreira Sales, 2002a.

.Realidades e ficções na trama fotográfica. 3. ed. São Paulo:Ateliê Editorial, 2002b.

LEITE, M.L. M. Retratos de família: leitura da fotografia histórica. São Paulo: Edusp, 2001.

LIMA, S. F. O circuito social da fotografia: estudo de caso II. In:FABRIS,Annateresa (Org.).Fotografia: usos e funções no séc. XIX. São Paulo: Edusp, 1991.p. 59-82.

MACHADO,A. A ilusão especular: introdução à fotografia. São Paulo: Brasiliense, 1984.

MENESES, U.T. B. Fontes visuais, cultura visual, História visual. Balanço provisório, propostas cautelares. Revista Brasileira de História, São Paulo, v. 23, n. 45, p. 11-36, 2003.

MONTEIRO, C. Porto Alegre: urbanização e modernidade: a construção social do espaço urbano. Porto Alegre: Edipucrs, 1995.

NEWHAL, B. Historia de la Fotografía: desde sus orígines hasta nuestros días. Barcelona: Gustavo Gili, 1983.

PESAVENTO, S. J. Exposições universais: espetáculos da modernidade do século XIX. São Paulo: Hucitec, 1997.

O imaginário da cidade: visões literárias do urbano, Paris, Rio de Janeiro, Porto Alegre. Porto Alegre: Editora da UFRGS, 1999. 
PHILLIPS, C. La photographie des années vingt: l'exploration d'un nouvel espace urbain. $L a$ Recherche Photographique, Paris, n.17, p. 30-37, automne, 1994.

POSSAMAI, Z. R. Nos bastidores do museu: patrimônio e passado da cidade de Porto Alegre. Porto Alegre: EST, 2001.

SANTOS,A. R. A fotografia e as representações do corpo contido (Porto Alegre 1890-1920). 2 v. Dissertação (Mestrado em Artes Visuais)-Programa de Pós-Graduação em Artes Visuais, Instituto de Artes, Universidade Federal do Rio Grande do Sul, Porto Alegre, 1997.

.O gabinete do Dr. Calegari: considerações sobre um bem-sucedido fabricante de imagens. In:ACHUTTI, Eduardo Robinson (Org.). Ensaios (sobre o) fotográfico. Porto Alegre: Unidade, 1998. p. 23-35.

SINGER, P. Desenvolvimento econômico e evolução urbana: análise da evolução econômica de São Paulo, Blumenau, Porto Alegre, Belo Horizonte e Recife. São Paulo: Nacional, 1974.

SOUZA, C. F.; DAMASIO, C. P. Os primórdios do urbanismo moderno: Porto Alegre na administração de Otavio Rocha. In: ROVATTI, J.; PANIZZI,W. Estudos urbanos: Porto Alegre e seu planejamento. Porto Alegre: Editora da UFRGS; Prefeitura Municipal de Porto Alegre, 1993. p.133-145.

Artigo apresentado em 07/2005. Aprovado em 03/2006. 